\title{
The influence of season and age on the levels of lipids, lipoproteins and enzymes in the serum of Lička pramenka sheep
}

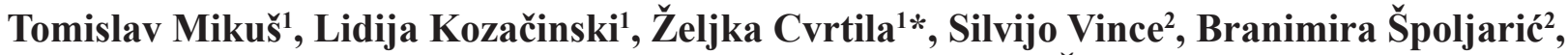 \\ Sonja Perkov ${ }^{3}$, Mirjana Marijana Kardum Paro ${ }^{3}$, Daniel Špoljarićc, Luka Pajurin ${ }^{4}$, \\ and Maja Popović ${ }^{4}$ \\ ${ }^{I}$ Department of Hygiene, Technology and Food Safety, Faculty of Veterinary Medicine, University of Zagreb, \\ Zagreb, Croatia \\ ${ }^{2}$ Clinic for Reproduction and Obstetrics, Faculty of Veterinary Medicine, University of Zagreb, Zagreb, Croatia \\ ${ }^{3}$ Department of Medical Biochemistry and Laboratory Medicine, Merkur University Hospital, Zagreb, Croatia \\ ${ }^{4}$ Department of Veterinary Biology, Faculty of Veterinary Medicine, University of Zagreb, Zagreb, Croatia
}

MIKUŠ, T., L. KOZAČINSKI, Ž. CVRTILA, S. VINCE, B. ŠPOLJARIĆ, S. PERKOV, M. M. KARDUM PARO, D. ŠPOLJARIĆ, L. PAJURIN, M. POPOVIĆ: The influence of season and age on the levels of lipids, lipoproteins and enzymes in the serum of Lička pramenka sheep. Vet. arhiv 91, 31-37, 2021.

\section{ABSTRACT}

This study aimed to identify seasonal and age related variability in triglycerides (TRI), paraoxonase (PON), stimulated PON (PON I) and cholesterol (CHOL, HDL, LDL) in extensively reared Lička pramenka sheep. The study was conducted 30 randomly chosen non-gravid Lička pramenka sheep on an extensive farm, grouped into three age groups in the Karlovac County, Croatia. Blood was collected by venepuncture of the jugular vein, twice in one year the first sampling in spring (April) and the second in autumn (October). The results showed that age had no significant effect on any of the investigated indicators, while seasonality significantly affected five out of the six parameters examined. Significantly higher levels of serum lipid components in autumn can be explained by the influence of the traditional way of rearing and feeding Lička pramenka sheep. Furthermore, the results of PON I in all three age groups showed that the sheep are well adapted to the environment and to the rearing system. Future research should be carried out on higher number of farms, and should include more sheep in order to determine objective benchmarks for serum lipids and the enzymes connected to those lipids.

Key words: sheep; plasma lipids; paraoxonase; cholesterol; seasonal variations

\section{Introduction}

The Mediterranean basin is an ancient sheep habitat and, compared to other species, local sheep farming is much more significant than in Northern Europe (SANUDO et al. 1998). In Croatia, as well as throughout Europe, sheep are bred in many

different systems, depending on the microclimate of the breeding area, and the purpose of the sheep or their products (VNUČEC, 2011). The Lička pramenka belongs to a group of medium-developed sheep, with high resilience and adaptability, and it

\footnotetext{
*Corresponding author:

Prof. dr. sc. Željka Cvrtila, PhD, Department of Hygiene, Technology and Food Safety, Faculty of Veterinary Medicine, University of Zagreb, Heinzelova 55, 10000 Zagreb, Croatia, Phone: +385 12390 190; Fax: +385 12390 192; E-mail: zcvrtila@vef.hr
} 
is a typical representative of one of nine Croatian indigenous sheep breeds (GRGAS, 2014).

Sheep's serum composition is important for assessment of the animal's health status. However, to be able to interpret collected biochemical data correctly, the results obtained in the laboratory must be compared with benchmark or so-called reference values. Numerous different factors such as species, breed, gender, age, diet, health, reproduction and seasonal variations can affect the serum composition (PERNTHANER et al., 1993; NAZIFI et al., 2003; YOKUS et al., 2006). Lipid compounds have ambiguous functions in animal's bodies, from physical insulation of the body and serving as a rich energy source through their metabolism, to forming the building materials of bio-membranes, hormones and hormone precursors. Lipoproteins are macromolecules composed of lipids and proteins (apolipoproteins) that are soluble in the majority of body fluids. Their major role in serum is transportation of lipids from the intestines and liver to peripheral tissues. In ruminants, the chemical composition and the rate of secretion of lipoproteins are among the main factors that control lipid utilization by tissues and, thereby, the qualitative and quantitative characteristics of meat production and milk yield (BAUCHART, 1993). Lipoproteins have been divided into several main groups: chylomicrons (CM), very-low-density lipoproteins (VLDL), low-density lipoproteins (LDL) and highdensity lipoproteins (HDL) (ENGELKING, 2015), and any major modification in their blood levels can lead to a variety of clinical disorders (ADAMU et al., 2008).

Paraoxonase (PON, aryldialkylphosphatase, EC 3.1.8.1) is an HDL-associated and calciumdependent ester hydrolase that catalyzes the hydrolysis of many xenobiotics, and its gene is expressed most in the liver (FERRE' et al., 2002; ROZEK et al., 2005). Although the blood concentration of $\mathrm{PON}$ is relatively stable throughout the lifespan of an individual (MACKNESS et al., 1998), it is influenced by diet, disease state, and other environmental factors (COSTA et al., 2003). These fluctuations are a repercussion of the specific characteristics of the PONs, as some remain inside the hepatocyte, and a portion is released into the blood stream where it binds to high-density lipoproteins (HDL) by coupling with apolipoprotein A1 (MACKNESS et al., 1998). Paraoxonase in sheep has been scarcely researched in the normal physiological status of the animal (KULKA, 2016), as most of the literature sources are related to some non-physiological life experiences which include higher levels of stress (DEVECI et al. 2018; SALAR et al. 2018). Recent studies show that PON I could have a role as an oxidative stress marker in veterinary medicine, similar to that in human medicine (KULKA, 2016).

Due to the difficulties of finding the benchmark values of several scientifically interesting serum lipids, lipoproteins and the enzymes connected to them, the aim of this study was to determine seasonal and age related variables in triglycerides (TRI), PON, stimulated PON (PON I) and cholesterol (CHOL) in extensively reared Lička pramenka sheep.

\section{Materials and methods}

Farm and animals. The research was conducted on an extensive sheep farm situated in Karlovac County, central Croatia, (for details see ŽURA ŽAJA et al., 2019). The herd is composed of 200 sheep and 20 rams of different ages, all of the Lička pramenka breed. The animals are kept extensively, grazing in the warmer periods of the year (Spring Autumn) and kept in the barn during winter months, when they are fed with hay from the surrounding fields.

Study design and blood collection. The research comprised 30 randomly chosen non-gravid Lička pramenka sheep, grouped into three age groups, with an average body weight of $35 \mathrm{~kg}$. All animals in the herd were registered with the Croatian Agricultural Agency and previous to the sampling, they were clinically inspected to confirm that they were in good health. Groups were organized as follows: Group A -one and two years of age; Group B - three years of age; Group C - four and five years of age. The sheep were clinically examined, their welfare was assessed, and their blood was drawn for further hematological analyses. Blood was collected by venepuncture of the jugular vein using vacuum-tubes with EDTA. After the venepuncture 
and blood collection into vacuum-tubes, $500 \mu \mathrm{L}$ of blood was separated into micro test tubes (BD Microtainer ${ }^{\circledR}$ Tube, $\mathrm{K}_{2}$ EDTA). The samples were then stored at $+4{ }^{\circ} \mathrm{C}$ and processed in the laboratory on the same day. Blood sampling was done in April and October 2018. Plasma was obtained by centrifuging the full blood for 15 minutes at 1500 G using a compact centrifuge HERMLE Z 206A (Labortechnik GmbH, Germany).

Biochemical analysis. All biochemical analyses were conducted in the biochemical laboratory of the Clinical Department for Medical Biochemistry and Laboratory Medicine, Merkur, Clinical Hospital, Zagreb, accredited by ISO 15189 through international guidelines for external quality assessment.

Triglycerides (TRI) and cholesterol (CHOL) concentrations were assayed using standard commercial kits (Beckman Coulter Biomedical Ltd., O'Callaghan's Mills, Co. Clare, Ireland) on an automatic Beckman Coulter AU 680 analyzer (Beckman Coulter Biomedical Ltd, Ireland). Triglycerides were measured by the photometric UV method. Cholesterol was measured by photometrics with cholesterol oxidase.

Basal (PON) and stimulated (PON I) catalytic activity of paraoxonase was determined by the spectrophotometric method on a selective biochemical analyzer, Olympus AU 600 (Olympus, Tokyo, Japan) at the Clinical Department for Medical Biochemistry and Laboratory Medicine, Merkur Clinical Hospital, Zagreb. The catalytic activity of the enzyme was expressed in international units per liter of serum $(\mathrm{U} / \mathrm{L})$, and in international units per mmol of HDL-cholesterol (U/mmol). Standardization of enzyme catalytic activities eliminated the possible influence of lipoprotein particle concentration on enzyme activity.

Ethics. All procedures conducted on animals used in this research were approved by the Ethical Committee for Veterinary Science, Faculty of Veterinary Medicine, University of Zagreb, Croatia (No.: 640-01/16-17/54; file No.: 251-61-01/139-162) and the Veterinary and Food Safety Directorate, Ministry of Agriculture, Republic of Croatia (No.: UP/I-322-01/17-01/31; file No.:525-10/0529-17-2).
Statistical analysis. The results were analyzed using the SAS 9.4 software package (Statistical Analysis Software 2002-2012 by the SAS Institute Inc., Cary, USA). Normal distribution of data was assessed with the PROC TRANSREG module, and in the case of non-normality, the transformation of variables was performed (log or exponential transformation) prior to analysis using the Box-Cox transformation. The mixed model (PROC MIXED) was used and the statistical model included the fixed effects of group and period. The animal effect on the repeated measurements over time was included in the model with a compound-symmetry structure. The multiple-comparison test of the least-square means with Tukey correction was performed. After the analysis, the data were back-transformed to the original values. Correlation analysis was performed using the module PROC CORR to calculate Spearman and Pearson correlations. Differences were considered significant when the $p$ value was below 0.05 .

\section{Results}

Although sheep were initially grouped in three age groups, the results collected showed no significant differences between the age classes for any of the preselected parameters (Table 1). For this reason, further data analysis was done on the collated results of all 30 sheep, taking only season into consideration (spring - autumn).

In contrast to age, seasonality had a major influence on levels of CHOL in sheep serum. The autumn results were significantly higher than spring samples. There were no major seasonal differences recorded regarding TRI levels (Fig. 1).

Further differentiation of CHOL on HDL and LDL sub variables also showed significant differences in favor of autumn sampling in both parameters (Fig. 2).

Fig. 3 shows the differences in levels of PON and PON I linked to spring and autumn. As well as the HDL and LDL, the results for PON and PON I also show significant difference between samplings, both in favor of the autumn sampling.

Through further statistical analysis of the obtained results, it was determined that there were positive correlations between CHOL and all the other recorded indicators (Table 2). 
T. Mikuš et al.: Season and age variations in blood serum lipids in Lička pramenka sheep

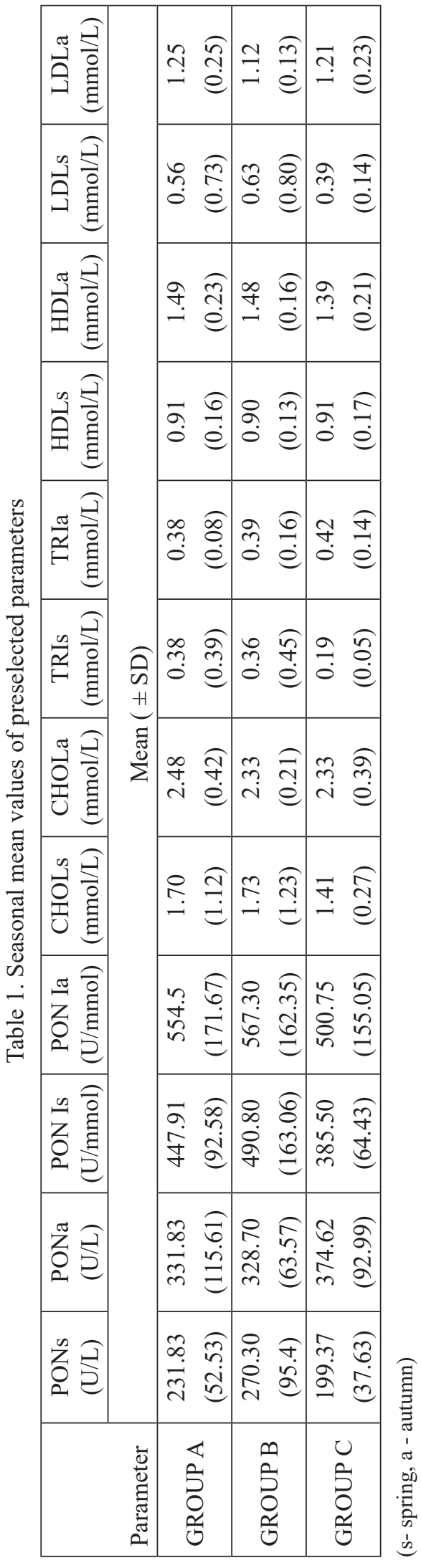

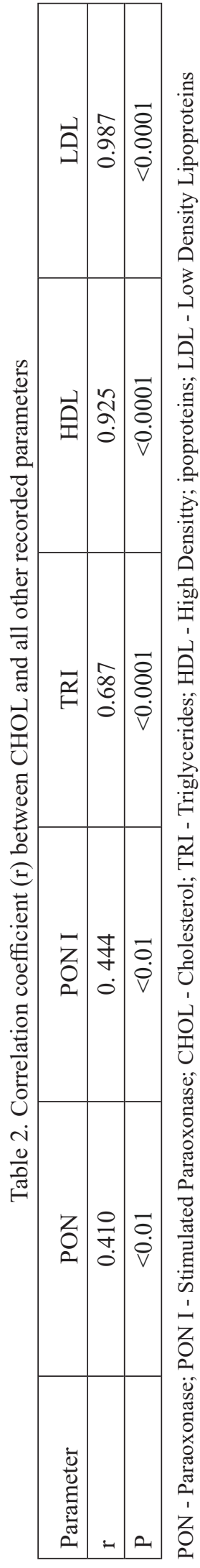

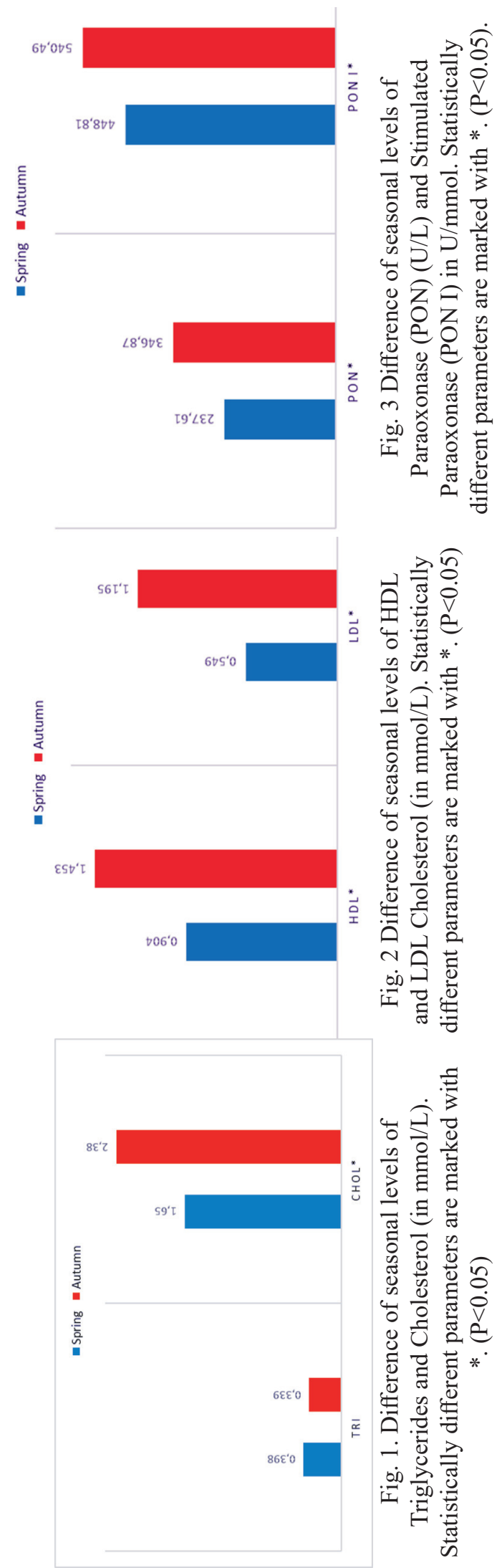




\section{Discussion}

Studies of basal physiological indicators in sheep blood serum are rare, and therefore there is a serious need to establish benchmarks, since even the physiological values that have been established are often only indicative in nature and depend on many external influences, such as the feeding or rearing system (YOKUS et al., 2006, SHEK VUGROVEČKI et al., 2017). Preselected nongravid animals were used as previous research has confirmed that pregnancy has a significant impact on serum lipids (NAZIFI et al., 2003), and the objective of this experiment was only to examine the influence of age and season on the preselected parameters.

The results show that age did not significantly affect any of the investigated indicators, which may be due to the somewhat small number of animals used in this research. Thus, in future studies a larger sample of animals from different farms should be considered, in order to obtain more certain and reliable baseline reference values for the monitored indicators.

In all three groups of sheep, the indicators CHOL, TRI, HDL and LDL (Table 1) were within (or very close to) the physiological limits common to traditional sheep breeds (NAZIFI et al., 2003; PICCIONE et al., 2009; NJIDDA et al., 2014), and unlike age, seasonality had a major impact on almost all the studied parameters, except TRI (Figs. 1-3). For all indicators with significant differences $(\mathrm{P}<0.05)$, all the values were significantly higher in autumn. This finding is in line with the research conducted so far in sheep (YOKUS et al., 2006; SABREEN et al., 2017), and other ruminants (YOKUS and CAKIR, 2006; TAJIK et al., 2013) reared in similar, more traditional conditions. The effect of seasonality on the levels of serum lipid components can be explained by the influence of the traditional way of rearing or feeding. Specifically, sheep in the Lika region traditionally graze during the late spring and summer months on nutrient-rich pastures, in a mild climate that favors the accumulation of proteins, and subsequently fat (ANTUNOVIĆ et al., 2002). In the winter, in traditional rearing systems, such as the one used in this research, feeding is based on voluminous dry fodder, and the quality and nutritional value of such fodder declines during the winter (HOFFMAN et al., 1993) and is at its lowest in the early spring. It is important, therefore, that seasonal variations must be taken into consideration for the correct interpretation of serum lipids in sheep.

Paraoxonase in sheep is a rarely researched enzyme and very often studies are based on determining PON and PON I levels in relation to certain pathological conditions (STEFANOVIĆ et al., 2009; CAO et al., 2017; DEVECI et al. 2018) rather than a physiological or seasonal parameter. MIKAIL et al., (2011) found that PON and PON I levels in sheep differ on the breed level, and although the levels determined by this study are similar to their findings, they cannot be objectively compared. However, although it is not possible to objectively compare the established levels of PON and PON I with other sheep breeds, the results show that PON I in all three groups of studied sheep was at a physiological level, so it can be argued that the sheep were well adapted to the conditions and manner of keeping (MIKAIL et al., 2011; CERON et al., 2014).

The correlation of cholesterol with all other monitored parameters is emphasized because cholesterol is involved in the metabolism of all the other compounds studied. The positive correlation that is visible in Table 2 speaks in favour of this, and indicates that even data on serum cholesterol levels alone can provide a good insight into the status of the other parameters monitored, and as such can contribute to our understanding of the metabolic status of the animals.

\section{Conclusions}

The Lička pramenka is the most common Croatian breed of sheep, but it is still very difficult to find the representative, physiological levels of serum lipids, lipoproteins and paraoxonase in the current scientific literature. Age had no significant effect on any of the six monitored blood serum indicators. Seasonality had an impact on five of the six monitored indicators in such a way that values in the autumn were significantly higher than those measured in the spring. 
The results presented in this paper, as far as the authors are aware, are the first of their kind, and will serve in future research. Future research should be carried out on more farms and a larger number of sheep in order to objectively determine the benchmarks of serum lipids and enzymes, and to enable better interpretation of the results.

\section{Conflicts of Interest}

The authors declare no conflict of interest.

\section{Acknowledgements}

This study has been fully supported by the Croatian Science Foundation under the project "Innovative functional lamb meat products (“Inojanjetina”)" (HRZZ-IP-06-2016-3685).

\section{References}

ADAMU, S, A. A. IGE, I. D. JATAU, J. S. NEILS, N. M. USEH, M. BISALLA, N. D. G. IBRAHIM, A. J. NOK, K. A. N. ESIEVO (2008): Changes in the serum profiles of lipids and cholesterol in sheep experimental model of acute African trypanosomosis. Afr. J. Biotechnol. 7, 2090-2098.

DOI: $10.5897 / \mathrm{AJB} 08.011$

ANTUNOVIĆ, Z., Đ. SENČIĆ, M. ŠPERANDA, B. LIKER (2002). Influence of the season and the reproductive status of ewes on blood parameters. Small Rumin. Res. 45, 39-44. DOI: 10.1016/S0921-4488(02)00109-8

BAUCHART, D. (1993): Lipid absorption and transport in ruminants. J. Dairy. Sci. 76: 3864-3881.

DOI: 10.3168/jds.S0022-0302(93)77728-0

CAO, Y., Z. JIANG, Y. WEI, X. CHENG, Z. HONG-YOU, W. YAN-HUI WANG, X. CHUANG (2017): Serum paraoxonase as an indicator for fatty liver in sheep. J. Vet. Res., 61, 97-102.

DOI: $10.1515 /$ jvetres-2017-0012

CERON, J. J., F. TECLES, A. TVARIJONAVICIUTE (2014): Serum paraoxonase 1 (PON1) measurement: an update. BMC Vet. Res., 10, 74.

DOI: $10.1186 / 1746-6148-10-74$

COSTA, L. G., R. J. RICHTER, W.-F. LI, T. COLE, M. GUIZZETTI, C. E. FURLONG (2003): Paraoxonase (PON 1) as a biomarker of susceptibility for organophosphate toxicity. Biomarkers, 8, 1-12.

DOI: $10.1016 /$ j.ccen.2004.09.019

DEVECI, H. A., A. KÜKÜRT, G. NUR, M. ALPAY, O. MERHAN, K. BOZUKLUHAN, V. YILMAZ, M. KARAPEHLIVAN (2018): Serum paraoxonase activity and total sialic acid in sheep with foot and mouth disease. Med. Weter. 74, 199-202.

DOI: $10.21521 / \mathrm{mw} .6078$
ENGELKING, L. R. (2015): Lipoprotein Complexes. In Textbook of Veterinary Physiological Chemistry (Third Edition). Academic Press. San Diego, USA, pp. 406-410.

FERRE', N., J. CAMPS, E. PRATS, E. VILELLA, A. PAUL, L. FIGUERA, J. JOVEN (2002): Serum paraoxonase activity: A new additional test for the improved evaluation of chronic liver damage. Clin. Chem. 48, 261-268.

GRGAS, A. (2014): Inherited breeds of sheep and goat in Croatia. Croatian agricultural extension service, Zagreb, $\mathrm{p}$. 6 (in Croatian).

HOFFMAN, P. C., S. J. SIEVERT, R. D. SHAVER, D. A. WELCH., D. K. COMBS (1993): In situ dry matter, protein, and fiber degradation of perennial forages. J. Dairy. Sci. 76, 2632-2643.

DOI: $10.3168 /$ jds.S0022-0302(93)77599-2

KULKA, M. (2016): A review of paraoxonase 1 properties and diagnostic applications. Pol. J. Vet. Sci. 19, 225-232.

DOI: 10.1515/pjvs-2016-0028

MACKNESS, B., P. N. DURRINGTON, M. I. MACKNESS (1998): Human serum paraoxonase. Gen. Pharmacol. 31, 329-336.

DOI: $10.1016 / \mathrm{s} 0306-3623(98) 00028-7$

MIKAIL, A., M. ERZENGIN, D. DEMIR (2011): comparison of serum paraoxonase 1 (pon1) activities among different sheep breeds in Turkey. J. Anim. Vet. Adv. 10, 489-494.

DOI: 10.3923 javaa.2011.489.494

NAZIFI, S., M. SAEB, E. ROWGHANI, K. KAVEH (2003): The influences of thermal stress on serum biochemical parameters of Iranian fattaile sheep and their correlation with triiodothyronine, thyroxine and cortisol concentrations. Comp. Clin. Path. 12, 135-139.

DOI: $10.1007 / \mathrm{s} 00580-003-0487-\mathrm{x}$

NJIDDA, A. A., A. A. SHUAI'BU, C. E. ISIDAHOMEN (2014): Haematological and Serum Biochemical Indices of Sheep in Semi-Arid Environment of Northern Nigeria. (GJSFR): (D) Agriculture \& Veterinary, 14, Issue 2. Available at: <https://journalofscience.org/index.php/ GJSFR/article/view/1171>. Date accessed: 22 Jan. 2020.

PERNTHANER, A., W. BAUMGARTNER, J. JAHN, W. PLAUTZ, T. ANGEL (1993): The hematologic parameters, concentrations of minerals and metabolic products and activities of enzymes in sheep. Berl. Munch. Tierarztl. Wochenschr. 106, 73-79.

PICCIONE, G., G. CAOLA, C. GIANNETTO, F. GRASSO, S. CALANNI RUNZO, A. ZUMBO, P. PENNISI (2009): Selected biochemical serum parameters in ewes during pregnancy, post-parturition, lactation and dry period. Anim. Sci. Pap. Rep. 27, 321-330.

ROZEK, L. S., T. S. HATSUKAMI, R. J. RICHTER, J. RANCHALIS, K. NAKAYAMA, L. A. MCKINSTRY, D. A. GORTNER, E. BOYKO, G. D. SCHELLENBERG, C. E. FURLONG, G. P. JARVIK, (2005). The correlation of paraoxonase (PON1) activity with lipid and lipoprotein 
levels differs with vascular disease status. J. Lipid Res. 46, 1888-1895.

DOI: 10.1194/jlr.M400489-JLR200

SABREEN. M. M. A., A. A. AL-ANI, T. S. AL-AZAWI (2017): Role of seasonal changes on serum ghrelin and lipid profile in Turkish Awassi Rams. Kufa J. Vet. Sci. 8, 141-150.

SALAR, S., I. BASSTAN, A. BASTTAN, M. PEKCAN, T. SEL (2018): investigation of changes in metabolic parameters and paraoxonase-1 during the transition period in turkish saanen goats. Kafkas. Univ. Vet. Fak. Derg. 24, 117-122.

DOI: $10.9775 / \mathrm{kvfd} .2017 .18479$

SANUDO, C., A. SANCHEZ, M. ALFONSO (1998): small ruminant production systems and factors affecting lamb meat quality. Meat Sci. 49, 29-64.

SHEK VUGROVEČKI, A., A. VOJTA, M. ŠIMPRAGA (2017): Establishing reference intervals for haematological and biochemical blood variables in Lika pramenka sheep. Vet. arhiv 87, 487-499.

DOI: $10.24099 /$ vet.arhiv.160314

STEFANOVIĆ, A., J. KOTUR-STEVULJEVIĆ, S. SPASIĆ, J. VEKIC, N. BUJISIĆ (2009): Association of oxidative stress and paraoxonase status with PROCAM risk score. Clin. Biochem. 42, 617-623.

DOI: 10.1016/j.clinbiochem.2009.01.008
TAJIK, J., A. SAZMAND, S. H. MOGHADDAM, A. RASOOLI (2013): Serum concentrations of thyroid hormones, cholesterol and triglyceride, and their correlations together in clinically healthy camels (Camelus dromedarius): Effects of season, sex and age. Vet. Res. Forum, 4, 239-243.

VNUČEC, I. (2011): Odlike trupa i kakavoća mesa janjadi iz različitih sustava uzgoja. Doctoral Thesis. Faculty of Agriculture, University of Zagreb, Zagreb, Croatia.

YOKUS, B., D. U. CAKIR, Z. KANAY, T. GULTEN, E. UYSAL (2006): effects of seasonal and physiological variations on the serum chemistry, vitamins and thyroid hormone concentrations in sheep. J. Vet. Med. A. 53, 271276.

DOI: $10.1111 /$ j.1439-0442.2006.00831.x

YOKUS, B., D. U. CAKIR (2006): seasonal and physiological variations in serum chemistry and mineral concentrations in cattle. Biol. Trace Elem. Res. 109, 255-266.

DOI: 10.1385/BTER:109:3:255

ŽURA ŽAJA, I., S. VINCE, N. POLJIČAK MILAS, I. R. ALBIN LOBPREIS, B. ŠPOLJARIĆ, A. SHEK VUGROVEČKI, S. MILINKOVIĆ-TUR, M. ŠIMPRAGA, L. PAJURIN, T. MIKUŠ, K. VLAHOVIĆ, M. POPOVIĆ, D. ŠPOLJARIĆ (2019): a new method of assessing sheep red blood cell types from their morphology. Animals 9, 1130.

DOI: $10.3390 /$ ani9121130

Received: 30 January 2020

Accepted: 8 Sptember 2020

MIKUŠ, T., L. KOZAČINSKI, Ž. CVRTILA, S. VINCE, B. ŠPOLJARIĆ, S. PERKOV, M. M. KARDUM PARO, D. ŠPOLJARIĆ, L. PAJURIN, M. POPOVIĆ: Utjecaj sezone i dobi na razinu lipida, lipoproteina i enzima u serumu ovaca pasmine lička pramenka. Vet. arhiv 91, 31-37, 2021.

\section{SAŽETAK}

Istraživanje je imalo za cilj identificirati sezonske i dobne varijacije triglicerida (TRI), paraoksonaze (PON), stimulirane paraoksonaze PON (PON I) i kolesterola (CHOL) kod ekstenzivno držanih ovaca pasmine lička pramenka. Iz Karlovačke županije u Hrvatskoj, nasumično je odabrano 30 ekstenzivno uzgajanih, negravidnih ličkih pramenki, raspoređenih u tri dobne skupine. Krv je uzorkovana iz jugularne vene, dva puta u jednoj godini - prvo uzorkovanje obavljeno je u proljeće (travanj), a drugo ujesen (listopad). Rezultati pokazuju da dob ovaca nije znakovito utjecala ni na jedan istraživani pokazatelj, dok je sezonalnost znakovito utjecala na pet od šest analiziranih pokazatelja. Znakovito viša razina lipida i lipidnih spojeva u serumu ujesen može se objasniti utjecajem tradicionalnog načina uzgoja i hranjenja ovaca pasmine lička pramenka. Nadalje rezultati PON I u svim trima dobnim skupinama potvrđuju da su ovce dobro prilagođene okolišu i sustavu u kojem se drže. Buduća istraživanja trebala bi se provesti na većem broju uzgoja/farmi i trebala bi uključiti više ovaca kako bi se objektivno ustanovile referentne vrijednosti serumskih lipida i enzima povezanih s tim lipidima.

Ključne riječi: ovce; lipidi plazme; paraoksonaza; kolesterol; sezonske varijacije; dob 
